\title{
The Role of the UN International Law Commission in the Codification of International Law
}

\author{
Pedro Keil
}

\begin{abstract}
The creation of the International Law Commission arouses from the necessity imposed by the text of the UN Charter. According to article 13 paragraph 1 (a) of the Charter of the United Nations, the General Assembly is responsible for the promotion of the progressive development of international law and codification of such. In this regard, the Resolution 174 (II) of 21 November 1947 came with this purpose. So, the Commission's nature is of an institutional and permanent subsidiary organ to the General Assembly of the $U N$, serving the purpose of perfecting the sources of law in the international ambit.
\end{abstract}

\section{INTRODUCTION}

Historically, it can be said that the first attempt to codify international law by an international organization was the League of Nations Codification Conference of 1930, that was an enterprise of unifying international law through a committee of experts. So, when the United Nations substituted the League of Nations after World War II, it was only natural that this goal remained pursued, and that's why the ICL was created.

The ILC is composed of thirty-four jurists, elected directly in the UN General Assembly, that organize and draft pieces of legislation that were already existent in the costumery form ${ }^{1}$, on one hand, and develop legislation when there's not uniformity in the international scenario. They do not represent member States in any way but propose new drafts of law accordingly to their own conscience and opinion ${ }^{2}$. However, the composition of the ILC is divided proportionally to the different legal regions in the world ${ }^{3}$, so that the work of the Commission translates the plurality of legal doctrines worldwide.

The work of the Commission can be a piece of legislation ready to be source of law or can indicate that the General Assembly approve some document if it needs another type of legal form, like a resolution or even a convention ${ }^{4}$. The form in which the Commission make its drafts public are through their Yearbook of the International Law Commission and other various documents. Even the

1 Some examples are: Treaty on the Non-Proliferation of Nuclear Weapons (1968), Convention on the Elimination of All Forms of Discrimination Against Women (1979) and Convention on Biological Diversity (1992).

${ }^{2}$ The Work of The International Law Commission, p. 9.

${ }^{3}$ Idem, p. 11.

${ }^{4}$ Idem, p. 50. travaux préparatoires have to be made public, in order for the law community to better interpret the meaning of the Commission's works.

\section{SOURCES OF INTERNATIONAL LAW}

The formation of international law differs a lot in comparison to domestic law orders and is the result of complex political and economic process ${ }^{5}$. According to some $^{6}$, international law was developed mainly in horizontal relations in inter-state agreements expressed freely. Considering the sources of law, treaties are a concrete form of international legislation, since the signing parties are obliged to act in accordance to what's been agreed upon, with specific terms. As for the rest of the sources, it is commonly asserted that custom is the other most important source of rules and, in a more general sense, settles a framework for international relations between States.

What is considered custom is the practices accepted by State interaction in usual situations which constitute what is called opinion juris, i.e., established rules that are already practiced and accepted and are already in a state of "crystallization" in international legal relations, being considered as binding. In that sense, is not a source constituted in a formal procedure in expressed accordance, but rather a tacit stabilization, produce by diffuse acts of the States, of rules and principles in the global sphere.

Wood ${ }^{7}$ argues that the customs have an objective element, that is the use of the practice, and a subjective element, which is the conviction in the obligation produced by international customs.

In this sense it is important to remark that international law must always aim at being effective ${ }^{8}$ (the subjects comply with it), complete (they should handle any situation) and unitary (as much as possible should the sources be unified in a manner as not to collide, or at least have a clear sub-rogation rule).

\footnotetext{
5 M. Danilenko, Gennady. The Theory of International Customary Law, p. 9.

6 Motataianu. Stefan. Public International Law SourcesHierarchy or Equivalence? 2011, p. 199 ss.

7 Wood, Michael. The UN International Law Commission and Customary International Law, p. 16.

${ }^{8}$ Motataianu. Stefan. Idem, p. 200.
} 
Unfortunately, the current reality is of a noticeable process of fragmentation in international law, in which risks the systematic vision of international legal order. Some of the factors for this phenomenon is the proliferation of international organizations and the creation of particular judicial regimes.

The general problem is that this specific source of law (custom) is by nature mostly uncertain, that is, it is not easy for the interpreter to identify clearly what is actually a common accepted practice and what is not ${ }^{9}$. In this situation enters the ILC, which is both in charge of codifying international law and of developing progressive said law, which would mean the clarification by a recognized body of the UN of the sources already consolidated internationally.

In this state of things, reaffirming the prevalence of customary law, codified by the competent organ, can unify this field of legislation. By assuring that the different hierarchical values of the international sources are affirmed can the ILC stablish certainty in international law scenario, and also avoid creative, and sometimes fanciful, mental gymnastics ${ }^{10}$.

This way the Commission acts both to develop international law and advance the codification procedure, which are both indistinguishable for the said organ ${ }^{11}$. It makes sense, considering that there's no fine line dividing which is which. Codifying customary law is a way to develop international law, so maybe the relation between the two should be recognized as more intricate than realized beforehand.

The intricacy of development and codification was already stated in 1950, when the member of ILC, Mr. Hudson, said that "there could be no codification without development".

\section{CUSTOMARY LAW AND THE ILC}

When the ILC Statute was established, international legislation was mainly customary ${ }^{12}$. This situation is in process of changing, mostly due to the Commission's work. It is needed to be pointed out that this work is not of legislature, as neither is the General Assembly's (its resolutions are not binding). In fact, if either body worked in the sense of producing new legislation, going beyond the development or codification of existing laws, it would be an ultra vires action ${ }^{13}$.

So, in order for the ILC to act as codifier, it should be already be "extensive State practice, precedent and

\footnotetext{
${ }^{9}$ M. Danilenko, Gennady. Idem, p. 18.

10 Fesler, Andy. Reformulating Customary International Law. 1998, p. 10.

11 And maybe even indistinguishable. Wood, Michael. The UN International Law Commission and Customary International Law, p. 7.

12 Wood, Michael. Idem, p. 1.

${ }^{13}$ Wood, Michael. Idem, p. 3.
}

doctrine", as the article 15 of the Statute states. In the case of the development of international law, it is supposed that there's not yet sufficient State practice in the specific matter, but in this situation the acts of the Commission should be limited to prepare conventions that are convenient to international relations, and not the active proposition of new rules $^{14}$.

The objective of codification is mainly to embody rules in a systematic written form that clarify the meaning and make said rules certain and consistent. The exact extension of this process has been in debate for a long time, as it is not clear what lex non scripta should take the form of written pieces of legislation and how these pieces should look like. It can be said that two main views arouse from this concept ${ }^{15}$ : codification can mean the declaration of existing rules, no matter their content (even if it is obsolete or inadequate) or it can mean the declaration of rules pertinent to the global scenario, or as they ought to be. This second meaning defies the impossibility for the Commission to legislate, so the first acceptation (the narrow sense) is probably more adequate.

The codification has to goal of completion, i.e., of implicating all rules that already don't have a formal appearance. Even so, it may be too idealistic to keep that as a possibility for the near future, and so, the practice of codification must focus on the clear gaps ${ }^{16}$ that may appear in the international law spectrum. That view is not exactly in accordance to the narrower interpretation of what codification is but can be seen as a preference for codification to the more relevant or urgent matters in international law. It is also another argument for the indistinction of law development and law codification: codification is a way to develop the science of international law, so the relationship between these two concepts is more of means to an end: the codifications as the means to attaining the end of law development $\mathrm{t}^{17}$.

\section{ILC'S CODIFICATION}

Apart from the general problems of interpretation of the opinio juris, referred in the beginning, it must be added the problems concerning the function of the ILC when visualizing the customs in order to codify them. Is that sense, the Commission's $40^{\text {th }}$ Meeting Yearbook ${ }^{18}$ shed some light to problems that arise from the ILC's practice and will be object of scrutiny hereafter. This question is one

14 Also, it is supposed that in the case of progressive development the ILC would act only with the initiative of the General Assembly. In the case of codification, the Commission would intitled to act ex officio. This differentiation is based on political implications. Wood, Michael. Idem, p. 4.

${ }^{15}$ Wood, Michael. Idem, p. 6.

${ }^{16}$ Wood, Michael. Idem, p. 10.

${ }^{17}$ Interpretation which can be based on the pronunciation of Mr. Hudson, supra quoted.

18 Yearbook of the International Law Commission 1950, Vol. I, 4, para. 5 . 
of methodology of codification ${ }^{19}$, that is, the concrete observation of their object of work, and not an abstract conceptional problem.

In order to better identify the general accepted rules of custom international law, the ILC addressed the States to make evidence of their practices more accessible to the Commission. In the same sense, the articulation of States and the Commission has proved to be fundamental in the work developed by the latter, as was already in the text of the Statute in 1947 in its article 26 (1).

When dealing with the precise contours of the custom law, it may happen that the interpretation is disputed. In that case, the Commission's duty is to observe the context of the situation $^{20}$ in with the rule was obeyed, in order not to generalize it to different cases. The opinio juris is not observed exactly in the text but more in the practice of the States, due to the element of conviction supra mentioned.

Another thing to keep in mind is that is not only the action of the States directly, but also the actions of international organizations that the State is member ${ }^{21}$. This is mainly due to the fact that a member of the IO is compliant to the organization's actions and the fact that the organization can't be a safe haven to practices that the member doesn't want to be recognized as an accepted rule. Even so, actions taken by individuals, i.e., not direct or indirect action of the State, should not be reputed as practices obeyed as international law, and in consequence, cannot be regarded as opinio juris.

The same legal document (Commission's $40^{\text {th }}$ Meeting Yearbook) foresee other sources of law, considered secondary means of interpretation. That is, inter alia, doctrine of recognized scholars, which helps in the integration process for the ILC's work. The caution should be to use the dogmatic approach of said scholars, and not lex desiderata, i.e., the law how it should be in order to be more just $^{22}$.

\section{PROBLEMS WITH CODIFICATION BY THE ILC}

It can be said that a part of the international law doctrine sustains a pessimistic view of the job delegated to the Commission for a number of reasons. The criticism can start with the fact that customary law has the advantage of being an amorphous body of source, which can be object to an intensive creative exercise by interpretation. The vagueness, in that sense, would be a virtue when interpreting rules made by countries of very different cultures, because the literally meaning of a codification can't admit flexibility when a particular court interprets the meaning of customs ${ }^{23}$.

\footnotetext{
${ }^{19}$ Wood, Michael. Idem, p. 14.

${ }^{20}$ Wood, Michael. Idem, p. 17.

${ }^{21}$ Wood, Michael. Idem, p. 19.

${ }^{22}$ Wood, Michael. Idem, p.24.

${ }^{23}$ Stone, Julius. On the Vocation of The International Law Commission, p. 18.
}

Another problem that can be mentioned is that the work of codification cannot possibly be "impartial", in the sense that it only formalize existing customs: when formulating rules in a different form, this declaration is always a legislative activity, because the option for this or that approach cannot be entirely neutral. If that really is so, the Commission would have law-making powers ${ }^{24}$, even if they're not recognized by the body as so.

Also, there's practical problems. For instance, sometimes the signatory countries may adopt a treaty with reservations, so the codification cannot be entirely applied to the legal reality in these situations.

Moreover, the codification would be dependent on the validity of the treaties subjacent of State practice. If a treaty is terminated it would mean that the codified piece of legislation is no longer lawful. It would be a rebus sic standibus situation, that in no way contributes to legal security (which is one of the very aims of the codification process). That is because, even though the texts produced by the ILC are enforceable, they are totally dependent on the custom law, which is the real source from where the ILC provisions keep the quality of been binding ${ }^{25}$. It would be regularly necessary for the processual parties to prove in court that determined ILC text is based on actual customary rules, otherwise they would remain unlawful.

\section{CONCLUSION}

All these problems in international codification imply a review in the objectives of the International Law Commission. In that sense, Stone suggests a shift in the mission performed by the ILC: instead of being the enunciator of international law, the Commission could act as a "international research center" ${ }^{26}$ ". That would mean that, recognizing the need for a centralized body of international law, the ILC should actually act more as a development law center, which would study the current problems with international society with the freedom from the pressure of political acceptance of their draft instruments (as the Commission is not representative of UN members and also because it have no legislative competence whatsoever).

This may be too radical of an approach, considering that the goals of the ILC are stated in the UN Charter, as above mentioned. In any case, the role played by the ILC should be performed with caution. In one hand the "pure" form of codification ${ }^{27}$ has never quiet worked, because what the ILC produces is always partial in a way ${ }^{28}$. It is especially important that the body attains itself to the textual limits imposed by its Statute and abide by their rules of interpretation of customs. The emphasis of the

\footnotetext{
${ }^{24}$ Stone, Julius. Idem, p. 19.

${ }^{25}$ Stone, Julius. Idem, p. 29.

${ }^{26}$ Stone, Julius. Idem, p. 49.

27 That is, the act of only "formalizing" what is already binding law.

28 Pellet, Alain. Between Codification and Progressive Development of Law: Some Reflections From the ILC, p.15.
} 
Commission's job must be the correct understanding ${ }^{29}$ of the rules in the international reality and never usurp to itself the position of a rule imposing body.

\section{REFERENCES}

[1]. FESLER, Andy. Reformulating Customary International Law, 1998.

[2]. M. DANILENKO, Gennady. The Theory of International Customary Law, 1988.

[3]. MOTATAIANU, Stefan. Public International Law Sources - Hierarchy or Equivalence?, 2011.

[4]. PELLET, Alain. Between Codification and Progressive Development of Law: Some Reflections From the ILC, 2004.

[5]. STONE, Julius. On the Vocation of The International Law Commission, 1957.

[6]. WOOD, Michael. The UN International Law Commission and Customary International Law, 2016.

[7]. The Work of The International Law Commission, 2012.

[8]. Yearbook of the International Law Commission 1950, Vol. I, 4, para. 5.

${ }^{29}$ Pellet, Alain. Idem, p. 16. 